\title{
Behandling og oppfølging av mennesker i selvmordskrise
}

\author{
Ved Georg Schjelderup
}

\begin{abstract}
Mer enn 7000 mennesker prøver å ta livet sitt hvert år $i$ Norge. Likevel regner vi med at kun en liten del av disse kommer $i$ kontakt med behandlings-og hjelpeapparatet. Undersøkelser kan tyde på at så mange som ca $40 \%$ av pasienter som har vært behandlet i forbindelse med et selvmordsforsøk, ikke følger opp videre behandlingskontakter (Runeson og Wasserman 1994). Andre studier viser at bare halvparten av ungdom og unge voksne overholder den første behandlingsavtalen utenfor sykehuset, og kun en tredjedel møter opp til så mange som tre timeavtaler (Brent og Kolko 1990).
\end{abstract}

Frafallsprosenten og den relativt høye dødeligheten blant disse pasientene stiller store faglige krav til intervensjonen som giøres etter et selvmordsforsøk. De behandlings- og oppfølgingstilbudene som helsevesenet i dag tilbyr pasienter etter et selvmordsforsøk, er ulike både med hensyn til kvalitet og varighet. En unders $\varnothing$ kelse fra Troms $\varnothing$ av 90 innleggelser for selvmordsfors $\varnothing \mathrm{k}$ viser at hos $1 / 3$ av pasientene var det ikke mulig å finne dokumentasjon for at pasientene var gitt tilbud om samtale omkring selvmordsfors $ø$ ket (Berntsen og Husby 1994). I Oslo er det mindre enn $10 \%$ som flyttes over til psyki-atriske avdelinger. Dette er meget lavt sammenliknet med f.eks. Stockholm og Lund der ca. halvparten blir overført til psykiatrisk avdeling etter selvmordsforsøk (Retterstøl 1995). Undersøkelser viser at ca. $10 \%$ gjentar selvmordsfors $\emptyset$ ket senere $i$ livet, og det første året er særlig kritisk i så henseende. Dette medfører ekstra belastninger for den enkelte og familien, men også for helsepersonell stiller dette store krav til den enkeltes faglighet og menneskelighet. Til nå har den systematiske oppfølgingen av disse pasientene vært mangelfull de fleste steder.

\section{Situasjonen i Aker sektor}

I Aker sektor i Oslo som har et befolkningsgrunnlag på ca. 130000 mennesker, fant vi i en forunders $\varnothing$ kelse at det årlig behandles ca. 180-190 pasienter etter «intoks» på medisinsk avdeling (hovedsakelig medisinsk mottagelsesavdeling). Ikke alle disse er selvmordsfors $\varnothing \mathrm{k}$. Samtidig fant vi at et tilsvarende antall pasienter hjemmehørende i Aker sektor med alvorlige selvmordstanker eller selvmordsplaner hvert år er innom psykiatrisk vakttjeneste i Oslo (spesialistlegevakt). Dersom vi antar at om lag 300 av disse pasientene er suicidale i den grad at de har behov for videre oppfølging og behandling, og samtidig antar at ca. $40 \%$ faller fra med dagens system eller ikke møter til henvisningssted, vil estimert frafall dreie seg om rundt 120 mennesker $\mathrm{i}$ året.

Erfaringer fra Bærum kommune hvor man har hatt en tiltakskjede etter selvmordsfors $ø$ k fra 1983, viser bl.a. en lavere prosentandel recidiv blant dem som blir fulgt opp i tiltakskjeden, enn hva man har funnet $i$ andre materialer. Vi $\emptyset$ nsket derfor å etablere et tilsvarende tilbud til pasienter hjemmehørende i Aker sektor. Det ble derfor vedtatt i administrasjonsmøte 4/12-96 å opprette et "ombudsteam" for mennesker i selvmordskrise. Teamet har vært operativt siden 1. januar 1998. Opprettelse og drift av teamet er et samarbeidsprosjekt mellom Aker sykehus og bydelene: 14:Helsfyr/Sinsen, 16:Furuset,
17:Stovner, 18:Romsås, 19:Grorud, 20:Bjerke, 21:Grefsen/ Kjelsås. Ansvarlig for oppstart og koordinering er Seksjon for selvmordsforskning og -forebygging, Universitetet i Oslo.

Akerprosjektet har et tosidig siktemål:

1) Etablere et ombudsteam for mennesker i selvmordskrise, noe som innebærer å:

- Aktivt følge opp pasienter etter selvmordsfors $\phi k$, og s $\phi r g e$ for at de blir "loset" inn i det behandlings- eller hjelpetilbudet som allerede eksisterer $\mathrm{i}$ sektoren. Teamet skal dermed fungere som et bindeledd mellom pasienten og mulige hjelpere.

- Skape et mottakerapparat og samarbeidsledd som sammen med sykehusets samlede tjenester utgiør en fullverdig behandlingskjede for suicidale pasienter.

2) Gjennomf $\phi$ re en forskningsmessig evaluering som har fø̆lgende hovedmålsetting:

Klarlegge det kliniske forl $\phi$ pet hos pasienter etter selvmordsfors $\phi \mathrm{k}$ f $\phi \mathrm{r}$ og etter iverksettelse av et systematisk oppfølgingstiltak i Aker sektor av Oslos psykiske helsevern med henblikk på å bedre kunnskapene om hvilke elementer $i$ behandlingskjeden som er virksomme for ulike grupper av pasienter, og å bedre kunnskapene om årsaksfaktorene og sykdomsmekanismer i forhold til utvikling av suicidal adferd.

Den forskningsmessige evalueringen vil ikke bli utdypet nærmere her, men er likevel en svært viktig og omfattende del av prosjektet.

\section{Ombudsteamets funksjon}

"Ombudsteam for mennesker i selvmordskrise" er etablert for å sikre omsorg og behandling for pasienter som har gjort et selvmordsforsøk. En hovedfunksjon for teamet er å være ombud. Et ombud er i denne sammenheng en god hjelper som går inn i den akutte krisesituasjonen og handler aktivt for å redusere selvmordsfaren, og medvirker til å skape en umiddelbar forandring til det bedre for den selvmordstruede personen. Medlemmene i ombudsteamet skal ikke være en ny behandlingsinstans, men først og fremst en hjelp for mennesker som mangler initiativ og krefter til a ta seg frem i et til dels uoversiktlig system. Dette innebærer aktiv oppfølging, motivering, støtte og veiledning for å sikre at pasientene făr opprettet kontakt med hjelpeapparatet, slik at de blir sikret adekvat behandling og hjelp videre. Den videre behandlingen av selvmordsfors $ø$ kspasienter vil ivaretas av eksisterende tilbud innenfor sektoren. Dette innebærer at ombudsteamets kontakt med 
pasientene er tidsavgrenset; inntil en forsvarlig kontakt er opprettet med annen behandlings- eller oppfølgingsinstans,

eller vedkommende klarer seg ved hjelp av egne ressurser og st $\varnothing$ tte i nettverket. I en folder som vi deler ut til pasienter som har vært behandlet i forbindelse med et selvmordsfors $ø$, har vi forsøkt å konkretisere dette ved å sette opp følgende eksempler på hva ombudsteamet kan hjelpe med:

- Gi støtte i den første tiden etter sykehusoppholdet

- Hjelpe deg med å avklare hva slags hjelp du trenger videre

- Formidle kontakt med behandlere i din bydel

- Følge til behandlingsavtale

- Formidle kontakt med sosialkontor

- Formidle kontakt med familievernkontor

- Formidle kontakt med rusmiddelomsorgen

- Gi råd i vanskelige spørsmål

- Støtte og være til stede i samtale med familie og venner

- Støtte og være tilstede i samtale med arbeidsgiver

- Formidle kontakt med prest eller andre i din kirke

- Formidle kontakt med skolens lærere

\section{Sammensetning av teamet og bruk av ressurser}

Ombudsteamet består av syv psykiatriske sykepleiere, en fra hver bydel. Hver av disse er tilsatt i en $20 \%$ stillingsandel for å følge opp pasientene etter at de er utskrevet fra Aker sykehus. I og med at sykepleierne har sin hovedstilling i bydelshelsetjenesten, har vi av organisasjonsmessige hensyn foreløpig valgt å fordele arbeidet med de enkelte pasienter etter deres bydelstilhørighet. Dette kan selvsagt føre til ulik fordeling i arbeidsoppgaver mellom sykepleierne i teamet, men har så langt vist seg a være hensiktsmessig. Teamarbeiderne er sikret faglig veiledning eller konsultasjon på sitt arbeid. Dette blir bl a ivaretatt av en psykiater som for $\emptyset$ vrig er ansatt ved konsultasjonspsykiatrisk avdeling inne på sykehuset. Denne avdelingen har bl a som oppgave å føre tilsyn med selvmordsfors $\emptyset$ kspasienter innlagt på sykehuset. Selv om avdelingen ikke har noe formelt ansvar for det arbeidet som utføres av ombudsteamet, vil konsultasjonstilbudet også bidra til samarbeid mellom konsultasjonspsykiatrisk avdeling og ombudsteamet. Vi har også vært opptatt av å skape kontinuitet gjennom hele behandlingskjeden, og vi har derfor knyttet til oss to sykepleiere ved medisinsk mottagelsesavdeling og to sykepleiere ved kirurgisk avdeling. Disse deltar i møter med ombudsteamet inne på sykehuset, og dette gjør det mulig å sikre kvaliteten på oppfølgingen helt fra pasienten kommer inn på sykehuset til vedkommende er tilbake i sitt hjemmemiljø igjen. I bydelene er det etablert kontakt med en lang rekke instanser, og særlig de distriktspsykiatriske sentra oppfatter vi som viktige $i$ denne sammenheng.

\section{Forankring}

Prosjektet er initiert fra Seksjon for selvmordsforskning og -forebygging, men er forankret i eksisterende organisasjoner $\mathrm{i}$ bydelene og på sykehuset. Stillingene i prosjektet er finansiert av hver enkelt bydel og av Aker sykehus. Dermed vil det ventelig være naturlig at oppfølging av selvmordsfors $\emptyset$ kere vil kunne bli et varig tilbud til pasientene også etter at prosjektperioden er avsluttet.

\section{Undervisning - kompetanseoppbyggende tiltak}

Selv om alle som for tiden er involvert i prosjektet er fag. personer med lang klinisk erfaring, har vi lagt vekt på å gi en felles skolering før oppstart. Vi har derfor arrangert et kurs av en ukes varighet. Her ble det gitt en bred innføring i selvmordsproblematikken, fra samfunns- til individnivå. For å få en felles tilnærming til problematikken har vi valgt å legge oss på den samme forståelsesramme som det selvmordsforebyggende team i Bærum. Spesialpsykolog Gudrun Dieserud har gjort et viktig arbeid med å operasjonalisere Edwin Shneidmans selvmordsforståelse (Shneidman 1994) for denne type korttidsoppfølging. Det er i hovedsak dette tenkningsgrunnlaget vi bygger videre på i ombudsteamets arbeid. Samtidig er det planlagt regelmessige *verkstedsamlinger», der det vekselvis blir gitt rene forelesninger og arbeidet med gjennomgang av case.

\section{Veiledning og faglig ledelse}

Som nevnt har vi en psykiater som faglig veileder for teamets arbeid. Imidlertid kan det vise seg at det i faglige møter blir liten tid til å ivareta den enkelte sykepleierens følelser og reaksjoner i møte med det selvmordstruede mennesket. Vi har derfor valgt å sikre dette ved å tilby gruppeveiledning med en erfaren veileder som er psykiatrisk sykepleier. Innenfor denne veiledningstiden som foreløpig gis én time i uken, gis det rom for å ta opp for eksempel overførings- og motoverføringsreaksjoner, sorgreaksjoner $\mathrm{mm}$. I denne veiledningen vil man også arbeide med sentrale begreper som for eksempel håp og mening. Slik håper vi både å kunne ivareta personalet og ved felles anstrengelser å kunne arbeide med fagutvikling.

\section{Litteratur:}

Berntsen GK, Husby R. Behandling av selvmordsforsqkere $i$ et somatisk sykehus. Tidsskr Nor Liegeforen 1994; 114 (20): 2374-77.

Brent DA, Kolko DJ. The assessment and treatment of children and adolescents at risk for suicide. I: Blumenthal, SJ, Kupfer,DJ. (red.) Suicide over the life cycle: risk factors, assessment, and treatment of suicidal patients. Washington, DC: American Psychiatric Press, 1990

Retterstol N. Selvmord. Oslo: Universitetsforlaget, 1995

Runeson B, Wasserman D.

Management of suicide attempters:

What are the routines and the cost?

Acta Psychiatr Scand 1994; 90:222-28.

Shneidman E. Definition of suicide. New Jersey: Jason Aronson, 1994

\section{Georg Schjelderup} er stipendiat og utfører sitt doktorgradsarbeid i tilknytning til Akerprosjektet. Han har bred erfaring som psykiatrisk sykepleier og høgskolelektor ved Høgskolen i Oslo.

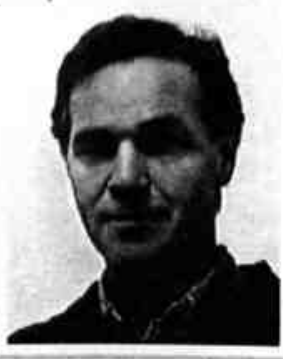

